\title{
FÍSTULA VESICOSIGMOIDEA EN ENFERMEDAD DIVERTICULAR, REPORTE DE CASO Y REVISIÓN DE LITERATURA.
}

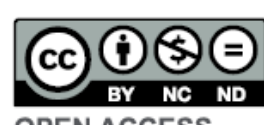

Este artículo está bajo una licencia de Creative Comlicencia de Creative Com-
mons de tipo Reconocimiento - No comercial - Sin obras Herivadas 4.0 International.

1. Hospital Quito $N^{\circ} 1$ de la Policía Nacional. Médico en funciones hospitalarias. Quito, Ecuador.

\section{ORCID ID:}

Pullupaxi Stefany Belén

orcid.org/0000-0003-4809-182

Portero Katherine Patricia

orcid.org/0000-0003-2657-6705

* Corresponding author:

Pullupaxi Stefany Belén

E-mail: tefy_bel@hotmail.com

Article history: Manuscript presented at the Clinical Case Contest - Hospital Vozandes Quito, February 27, 2021.

CARE 2017 Check List statement: The authors have real the CARE 2017 Check List and the manuscript was prepared and revised according to the CARE 2017 Checklist.

Conflict of interest: All authors declared that there are no conflicts of interest.

Financial disclosure: The authors have no financial relationships relevant to this article to disclose

Forma de citar este artículo: Pullupaxi SB, Portero KP. FÍSTULA VESICOSIGMOIDEA EN ENFERMEDAD DIVERTICULAR, REPORTE DE CASO Y REVISION DE

LITERATURA. Rev Med Vozandes. 2021; 32 (1 Suppl 1): S19-S20

\section{Resumen}

Introducción: Las fístulas colovesicales (FCV) son comunicaciones anómalas que se forman entre el intestino grueso y la vejiga. Representan 1 de cada 3000 admisiones hospitalarias quirúrgicas por año. Los estudios de imagen juegan un papel crucial en el establecimiento del sitio, curso y complejidad de las fistulas, y en la identificación de su etiología. El manejo de las FCV depende de la patología de base, el sitio de la lesión intestinal y el estado preoperatorio del paciente. Se puede realizar un enfoque quirúrgico y no quirúrgico

Descripción del Caso: Se reporta un caso clínico de un paciente de 82 años, con múltiples comorbilidades, quien presentó de forma súbita disuria, estranguria y fecaluria. La tomografía de abdomen y pelvis S/C reveló diverticulitis con presencia de trayecto fistuloso de colón hacia vejiga. Durante su hospitalización, el paciente presentó choque séptico de foco urinario por fístula colovesical, que requirió manejo por terapia intensiva. Se instauró antibioticoterapia de amplio espectro. Una vez estable, se optó por resolución quirúrgica con cistectomía parcial más fistulectomía y colostomía tipo Hartmann. Posterior al procedimiento, el paciente evolucionó de manera favorable con resolución del cuadro.

Conclusión: El enfoque no quirúrgico puede ser una opción viable en pacientes con mal estado preoperatorio, incapacidad de tolerar la anestesia general o en pacientes oncológicos con una esperanza de vida corta. El cierre espontaneo de las fístulas ocurre en aproximadamente el $2 \%$ de los pacientes y, dado que hasta el $75 \%$ pueden tener complicaciones sépticas, la presencia de una FCV es una indicación para cirugía en todos los pacientes sin contraindicaciones para ella. El enfoque quirúrgico más empleado consiste en la resección del segmento intestinal comprometido con anastomosis primaria, sin estoma de protección, y cierre del defecto de la vejiga. En la actualidad, no existe un consenso sobre cuál es la mejor estrategia quirúrgica debido a la falta de ensayos clínicos. Se realiza una revisión actualizada del tema y su manejo terapéutico. 
Keywords: Colovesical Fistula, Urinary Fistula, Intestinal Fistula, Vesical Fistula, Colostomy

\section{Abstract \\ VESICOSIGMOID FISTULA IN DIVERTICULAR DISEASE, CASE REPORT AND LITERATURE REVIEW.}

Introduction: Colovesical fistulas (CVF) are pathologic communications between bowel and bladder. They represent 1 in 3000 surgical hospital admissions per year. Imaging studies play a crucial role establishing the site, course and complexity of the fistulas, and in identifying their etiology. The management of CVF depends on the underlying pathology, the site of the intestinal injury, and the preoperative state of the patient. A surgical and non-surgical approach can be performed.

Case description: A clinical case of an 82-year-old patient with multiple comorbidities is reported, who suddenly presented dysuria, stranguria and fecaluria. The abdominal and pelvic tomography revealed diverticulitis with the presence of a fistulous tract from the colon to the bladder. During his hospitalization, the patient presented septic shock of urinary focus due to colovesical fistula, which required management by intensive therapy. Broad-spectrum antibiotic therapy was started. Once stable, we opted for surgical resolution with partial cystectomy plus fistulectomy and Hartmann-type colostomy. After the procedure, the patient evolved favorably with resolution of the condition.

Conclusion: The nonsurgical approach may be a viable option in patients with poor preoperative condition, an inability to tolerate general anesthesia, or in cancer patients with a short life expectancy. Spontaneous closure of fistulas occurs in approximately $2 \%$ of patients and, since up to $75 \%$ may have septic complications, the presence of a FCV is an indication for surgery in all patients without contraindications for it. The most widely used surgical approach consists of resection of the compromised intestinal segment with primary anastomosis, without a protective stoma, and closure of the bladder defect. At present, there is no consensus on which is the best surgical strategy due to the lack of clinical trials. An updated review of the subject and its therapeutic management is carried out. 